\title{
Women's Resistance in Indonesian Drama (A Gender Study)
}

\author{
Budi Waluyo $^{1}$, Andrik Purwasito ${ }^{2}$, Warto ${ }^{3}$, Slamet Subiyantoro ${ }^{4}$ \\ 1,2,3,4 Universitas Sebelas Maret, Indonesia ,Email: mas_bewe@yahoo.co.id
}

\begin{abstract}
Gender injustice problems experienced by women have led to the emergence of the women's resistance movement. Not only today, women's resistance to gender injustice has existed even before Indonesia gained its independence. Nyai Ontosoroh is one of the characters in Bumi Manusia, a novel written by Pramoedya Ananta Toer which reflects women's resistance to gender injustice during the Dutch colonial period. Nyai Ontosoroh's struggle in the novel was later adapted in a drama entitled "Nyai Ontosoroh" by R Giryadi. The main focus in the drama is Nyai Ontosoroh's resistance to various gender injustices she has received, including her resistance to the Dutch government. The figure of Nyai Ontosoroh is depicted as a Javanese woman who has gone far beyond her time. She fought for her destiny out of the colonialism of the mind and the occupation of freedom. She also has the courage to express her opinion openly and blatantly. This research aims to explain and describe forms of gender injustice and women's resistance in "Nyai Ontosoroh" drama. The descriptive qualitative method with a feminist approach was applied in the analysis. The description includes forms of gender injustice and women's resistance found in the drama. The conclusion of this paper shows that there are still many gender injustices experienced by women, even in their homes. The large number of injustices that occur against women certainly creates various forms of resistance to combat these injustices. Women must fight to get gender justice properly.
\end{abstract}

Keywords:

drama, resistance, gender injustice, Nyai Ontosoroh

Article Received: 18 October 2020, Revised: 3 November 2020, Accepted: 24 December 2020

\section{Introduction}

Gender injustice in society is nothing new. Fakih (2013: 13-23) defines gender injustice as a system and structure in which men and women are victims of the system. Gender injustice arises because of the existence of a system or structure regarding certain stereotypes. Gender inequality can be divided into five types: (1) marginalization of women, which is an act of marginalizing women, limiting their role to certain groups; (2) women's subordination, which is an act of degrading women, considers that women are not capable of making decisions; (3) stereotypes of women are views that give women certain stigma; (4) violence against women both physically and psychologically; and (5) double burden for women who work outside and are still have their duty to do housework.

Hazel \& Kleyman (2020: 281) state that even though the world has seen a big step towards gender justice, there are still many gaps that exist and there is a possibility of widening it. The existence of various gender injustices has led to various resistance movements to eliminate these injustices. One of the movements that emerged due to gender injustice was the feminism movement. Feminism is not an ideology that stands alone. Feminist thoughts and movements were born with a certain context, be it culture, religion, race, ethnicity, etc. Feminism does not only belong to women, this idea is born from the socio-cultural context that surrounds women in social life.

The problems that exist in real life are often reflected in various forms of literary works, one of which is drama. Drama provides a picture that occurs in everyday life that contains messages or criticism of society. Drama is an imitation of human life that is projected on the stage with various conflicts in it. Renggani (2014: 7) states that drama is a portrait of human life which contains experiences, joys and sorrows, and black and white of human life. Drama (Endraswara, 2014) is the most effective means of describing social and moral conflicts that exist in the community. Similarly, Lehtonen, Österlind, and Viiret (2020: 6) state that drama learning is 
process-oriented, with changes in space and time, which reflect real events and fantasies.

Gender injustice that occurs in society is one type of problems that often appears in Indonesian drama, especially in feminist drama. Feminist literary works are related to several aspects (Sehandi, 2014: 193), including: (1) expressing the works of past and present women writers to clarify the image of women who were bound by tradition, the dominance of patriarchal culture must be clearly expressed in the analysis; (2) describing the pressure experienced by female characters in literary works written by male authors; (3) revealing the ideology of female writers, whether or not they are unique in their styles and expressions; and (4) expressing aspects of feminist psychoanalysis, which is why women prefer things that are subtle, emotional, loving, etc.

A feminist drama or drama that tells the story of women is the object that will be studied further. The problem of gender injustice experienced by women has led to various resistance movements against it. "Nyai Ontosoroh" drama by R Giryadi, adapted from Bumi Manusia novel, is a drama that raises the issue of gender injustice and women's resistance to it. Through the character, Sanikem-later known as Nyai Ontosoroh-R. Giryadi shows various resistance by women. Not only did Nyai fight against her family, Nyai also bravely fought the will of the Dutch government regarding the custody of her child which could not fall on her for several reasons. Nyai, who was deliberately sold by her father for promotion, ended up becoming the mistress of TB Mellema, Tuan Besar (master) in Tulangan. The concubine (Baay; Subarkah, 2011: 24; Hardini, 2016: 99) is a slave girl who lives in a European household with all-in duties. The point is that they take care of all household matters, including satisfying the sexual needs of their masters. They are not a class of prostitutes who charge for services they have performed, nor are they legal wives because they have never been legally married. Nyai Ontosoroh who ended up being a concubine felt that she had lost her pride. Even so, his lost pride didn't make him give up on the situation. Nyai Ontosoroh is described as a woman who is persistent in fighting for her fate out of the colonialism of the mind, the colonialism of freedom, and at the same time always daring to express her opinion freely and openly.

Gender injustice experienced by female figures is triggered by gender inequality which prevails in the context of the Javanese cultural background, including the injustice experienced by Nyai Ontosoroh. Several studies stated that women's language is weak (powerless) compared to men's. This is because there is a subordinate assumption in the community that they are treated differently. What is considered polite to men does not apply to women. On the other hand, what is considered impolite for women can actually be accepted by men (Nurhidayah \& Nurhayati, 2018: 234-235). The existence of gender-biased cultural attitudes in Javanese culture is the trigger for the injustice that Javanese women received by men. Women are isolated in household work while men do various other more productive jobs. This understanding then gave birth to a patriarchal culture that places men as superior beings and brings women not only as subordinate parties, but also as parties who often receive improper treatment (Mujono and Zalhairi, 2015: 223). This is in line with Rini's (2019: 25) opinion that Javanese women, in some Javanese literary works, are positioned as konco wingking (only related to sexual needs and kitchen issues), swarga nunut neraka katut (women always follow their husbands, in good (heaven) and bad (hell) things)

Fernández, Quiroga, Escorial, \& Privado (2016: 130) have stated that the division of tasks based on gender affects several aspects of daily life for women and men, and generally disadvantages women. Similar to this opinion, Soeharto, Kuncoro, \& Prahara (2020: 1) state that the paradigm of women's roles is relatively unchanged, with some people still expecting women to take care of the house. This is certainly not a good thing, because men and women must have the equal justice regarding the division of 
tasks. Many women are capable of carrying out various matters outside of internal affairs at home, such as Nyai Ontosoroh who is able to do things that previously believed only men could do. Nyai also shows that women are able to stand on their own feet. The portrayal of Nyai Ontosoroh as a Javanese woman who is able to fight against gender injustice has attracted researchers to analyze gender injustice and women's resistance in "Nyai Ontosoroh" drama by R Giryadi.

\section{Research method}

This research employed qualitative descriptive method. The descriptive method according to Moleong (2014: 11) is a research method that produces data in the form of words, pictures, and not numbers. Through the descriptive method, the researcher made a systematic, factual, and accurate description of the drama to be analyzed. The approach applied in this research is a feminist approach. The feminist approach aims to identify gender injustice against women and reveal the forms of resistance that women do as resistance to gender injustice. The data in this study used the results of the analysis of $\mathrm{R}$ Giryadi's "Nyai Ontosoroh" drama in the form of words, sentences, and paragraphs.

The data analysis technique used in this research is content analysis. This study analyzed "Nyai Ontosoroh" drama and other relevant documents with the aim of obtaining the various data needed. Ismawati (2011: 81) states that content analysis is a research technique used to describe something objectively. This technique uses various procedures to draw conclusions about a book or document legally. The collected data were analyzed by the researcher in the following steps: (1) identifying and processing the data; (2) discussion of data; and (3) drawing conclusions.

\section{Result and Discussion}

The story of "Nyai Ontosoroh" is adapted from a famous novel entitled Bumi Manusia, written by Pramoedya Ananta Toer. The novel describes concubinage in the colonial era. It is often referred to as part of history even though it is written as a fictional story. In this novel, the story of Nyai
Ontosoroh is a prominent one. The depiction of the struggle of Nyai Ontosoroh, who was the mistress of Europeans, in fighting for her dignity has made many readers fall in love with her. His very interesting story was later adapted by $\mathrm{R}$. Giryadi into a drama entitled "Nyai Ontosoroh".

"Nyai Ontosoroh" drama tells of a Javanese woman whose real name is Sanikem-later known as Nyai Ontosoroh-whose freedom was deprived by her own father in order to get a promotion. Nyai Ontosoroh is described as the concubine of Tuan Besar Herman Mellema. However, there is a special difference between Nyai Ontosoroh and other concubines in general. Nyai Ontosoroh is described as a concubine who doesn't just give up on her fate. Despite the title of a "Nyai", she had the opportunity to learn to read, write, and even speak Dutch. She is also good at doing office affairs and is painstaking in doing all business matters. In short, Nyai Ontosoroh is a manifestation of indigenous women who have gone far beyond their time. Despite being a "Nyai", she is not described as a lowly woman. On the contrary, Nyai Ontosoroh is described as a typical indigenous woman who is intelligent, tough, assertive, and independent. She is described as a woman who is persistent in fighting for her fate out of the colonialism of the mind, the colonialism of freedom. She also has the courage to express her opinion openly and blatantly.

\subsection{Gender Injustice}

Various forms of gender injustice can be seen in various forms of scenes in Nyai Ontosoroh. Since the beginning of the scene, Sanikem - who later became known as Nyai Ontosoroh - had experienced injustice to the point that he lost his freedom because his father insisted on marrying him off to a rich man, no matter who the person was.

"No need to choose! Those poor cheesy guys, they don't deserve to be chosen. You are chosen to be the wife of a rich man, whoever he is!" (p.4, translated) 
Sanikem did not have the right to determine her own spouse. She had to comply with her father's wishes and marry any rich man who came to propose her. Sanikem's argument could not change Sastrotomo's will to marry him off to the rich. Even though in the end Sanikem's mother also rejected her husband's wishes, she initially agreed to his wish to immediately marry Sanikem to a rich man, even though for different reasons. Sanikem's mother supported the plan only for fear that Sanikem would become an old maid.

"Be strong, my dear. You're fourteen now. You've had your period. It's not good to be an old maid. So give up your youth." (p. 4, translated)

Sanikem's mother was more afraid of becoming the subject of neighbor's gossip than to make her daughter unhappy, so she told Sanikem to give up her youth and complied with Sastrotomo's wishes. Puspitasari, Nurhaeni, \& Muktiyo (2019: 5) state that the decision to marry at an early age is strongly influenced by a shame culture becoming the subject of neighbor gossip if their daughter does not immediately get married. Gender injustice appears strong in this scene. If a woman does not get married immediately, she will get gossip and insults, but this does not happen to men. If a man does not get married and remains single until he reaches maturity, society only sees it as something normal and not something to be ashamed of. Marphantia, Reid, \& Amable (2017: 4) state that women tend to get married at a younger age than men.

When she realized who Sanikem was going to marry, her mother finally defended Sanikem. She asked her husband not to marry Sanikem to Tuan Besar Mellema.

"No, don't do that! Why Ikem? Why did you give her to the big man? How could you?" (p. 4, translated)

However, Sanikem's mother's resistance meant nothing. Sastrotomo had firmly decided that he would marry Sanikem to Tuan Besar Mellema in order to fulfill his ambition of becoming a paymaster. He felt he had made the right decision by marrying off his daughter to the man.

"Shut up! I have tried to make my child a respectable woman. The wife of Tuan Besar. A great lord in Tulangan who is very rich and honorable. Sanikem will be honored. And we will be honored, too. Sanikem will be rich, she won't be homeless with those uneducated ghetto ass." (p. 5, translated)

Sastrotomo's remarks show that in his family, as in most Javanese families, men are the decision makers. As the head of the household, men take the lead in the family in deciding things. Sudarta (2017: 61) states that in recognized norms, it is husband who most often determines decisions in the family. It does not apply to all decisions, but in Sanikem's family, it happens too much. Men are indeed the final decision makers but deliberation still needs to be carried out so that decisions remain in the form of collective decisions not only one-sided will, as shown by Sastrotomo.

Even though Sanikem was asked to marry Sastrotomo, it turned out that she only ended up as the mistress of Tuan Besar Mellema, the Dutch who was the "great lord" in Tulangan. Her status as a concubine made her considered an immoral and unethical woman, so that society looked down on her. A lot of prejudice fell on her, even though she was only a victim of his own father's greed. In several parts of the drama, Sanikem told her life journey until she ended up becoming Nyai Ontosoroh.

"Sanikem is gone. Forever. Now, my name is Nyai Boerderij Buitenzorg. People call me Nyai Ontosoroh. The life of a Nyai is tough. She's only a slave with her duty to satisfy his master. In all respects! When the master's bored with her, she must be ready to be dumped, become poor, without the slightest right of resistance. One wrong step, she will be separated with her own child. Or 
even told to leave empty-handed." (p. 6 , translated)

"I had no right to decide my own future. Everything had been set up by my father. Your mom only had to wait for a man who would take her away from home to wherever he wanted. As the first or fourth wife, she never knew. My father, only my father had the right to make a decision. Whether the man was an old man or a younger one, a maid had no right to know. Once it happened, she had to devote her body and soul to the stranger, for the rest of her life, until she died, or until he was bored and dumped her. No other choice. It could be that he's a criminal, gambler, or drunk. The woman never knew until she became his wife. She'd be lucky if the stranger is a wise man and not yet married." (p. 15 , translated)

Women were considered as goods that can be traded and treated unfairly. They do not even have rights over themselves. That was what happened to Nyai Ontosoroh. She had to be ready for any possibilities. She might be willing to marry a man her father's choice of, without knowing who the man was and how many wives he had. She had to be ready to be dumped and kicked out of the house without bringing anything when his master was bored with her. Even if she had a child with her master, she had no right to take care of them, even though she is their biological mother. If the master wanted Nyai to bring their children, Nyai could take them. On the other hand, if Nyai was thrown away emptyhanded then she was not allowed to carry any property, nor could she carry her child.

"I went to the court yesterday to register us. It turned out that with legal intervention, Robert and Annelies were still considered illegitimate children and were only admitted as mine, Tuan Mellema's children.” (p. 16, translated)

As previously mentioned, Nyai had no rights over her biological child, even though she had brought the case to justice. Women who were concubines to Europeans at that time did not have custody of their biological children. This is in accordance with the opinion (Baay; Subarkah, 2011: 23; Hardini, 2016: 100) that it is really bad luck for the mistresses if they have children from their relationship with European men. The child will be taken and the mistresses will be expelled. As a result, many mistresses become lunatics, commit suicide, and live in misery.

\subsection{Women's Resistance}

Various gender injustices experienced by women have led to women's resistance movements, including in the story of Nyai Ontosoroh. The various gender injustices she has received since she was a teenager have made her a strong, independent, and firm woman. From the very beginning, Nyai showed her resistance. When she was about to be sold by her own father for promotion, she had already expressed her disapproval.

“That's right. I'm an adult now, but I

have the right to make choices." (p.4, translated)"

Since the beginning, Nyai Ontosoroh had stated firmly that she has the right to make her own choice in life, including her life partner. As stated by Wilujeng (2013: 160) that freedom is a human demand as an individual being. Human beings who live in society naturally possess rights and freedoms. Nyai Ontosoroh clearly expressed her disapproval of her 'father's plans to set him up with a rich man. Even though Nyai Ontosoroh's mother initially agreed to her father's wishes, she finally refused and fought because she could not bear to see Nyai marry Tuan Besar.

'No, don't do that! Why Ikem? Why did you give her to the big man? How could you?" (p.4, translated) 
Nyai Ontosoroh and her mother's objection regarding Sastrotomo's plan did not change his decision to still marry Nyai to Tuan Besar Mellema. Failed to fight for her rights, her pride was hurt. She decided to ignore them. Sanikem felt as if she slowly fused and transformed into Nyai Ontosoroh. For her, Sanikem was gone. When her parents came to visit her, she refused to meet them, as a form of her disappointment at what her parents had done to her.

"Sanikem is gone. Forever. Now, my name is Nyai Boerderij Buitenzorg. People call me Nyai Ontosoroh." (p. 6 , translated)

"Tell them, Sanikem no longer exists." (p.7, translated)

Tuan Besar Mellema was unable to persuade Nyai to meet her parents. Nyai refused to meet them. She even told Master Mellema that if she met them, it would mean Tuan Besar Mellema had returned her to them.

"If I meet him, it means you give me back to the previous owner. Should I go? What would it be if I couldn't be tough? I just couldn't heal the wound on my pride, my self-esteem. I still remember how it felt when he sold me to you. I can't forgive my father's greed and my mother's weakness. Once in a life, we should make our own decision. Never mind. Let the past go. That's the best I can do. Tell them to go home, or you will lose your cows and dairies. I have become an egg that fell from the nest. It's broken. But it's not its fault." (p. 8, translated)

What Nyai Ontosoroh did by rejecting her parents and threatening Tuan Besar Mellema is a form of resistance in facing the various gender injustices she has received. She deliberately chose to avoid her parents to show that the golden and the promotion that his father received meant that they lost her forever. As a girl, she had lost her right to choose her own way of life.

The various gender injustices she had experienced made Nyai Ontosoroh unwilling to depend on men. She tried to be a smart and independent woman.

“Everything I've learned during my life with Tuan Besar Mellema has brought back my self-esteem a little. But I've made my decision. I don't want to depend on anyone, anymore. For a Javanese woman, talking about self-esteem is too much. Besides, I was still too young to have a family. But then I finally realized that, I wasn't dependent on Tuan Besar Mellema. On the contrary, he was very dependent on me. I'd taken the stand to participate in deciding various matters. He never refused. In fact, he really forced me to continue studying." (p. 8, translated)

Nyai used the freedom Tuan Besar Mellema gave her to learn many things. She even studied Dutch even though at that time the Dutch government prohibited natives from studying, especially for girls. The aim was that the government could still colonize and there were no natives who had the intelligence to go against the Dutch government's will. Kartini wrote this in her letter to Mejufrouw Zeehandelaar, "When Javanese get an education, "they will no longer agree to anything their superiors order (Sundari, 2019: 280)". Kartini also stated that "one of the reasons for fighting for women's rights is a longing for freedom and independence, a desire to be independent" (Sundari, 2019: 278).

From Nyai Ontosoroh's marriage to Tuan Besar Mellema, two children were born. A girl named Annelies and a boy named Robert. Annelies is a beautiful and independent girl. She helps Nyai Ontosoroh in taking care of various jobs. Her experience as a girl who lost her freedom due to the greed of her parents made 
Nyai Ontosoroh give freedom to Annelies to decide for herself what she wants to do.

"Don't worry. Mama will handle everything. And finally, you have the right to decide. It's all up to you, Ann." (p. 15, translated)

Nyai fully supported her daughter and gave freedom to her to do whatever she choose. Nyai is not a parent who determines the path of life for her daughter. She was free to decide what she wanted to do.

Nyai's resistance did not only stop at various injustices caused by her parents but also for the injustice she received as a mistress in the eyes of the Dutch government. Dutch government law made her lose her rights over her daughter, even though she is the biological mother.

"I'm her mother, right? I was the one who conceived and gave birth. I took care of my daughter and raised her. This is the fact. Your law does not admit me as the mother of my own daughter, just because I am native and not legally married to you. Yes, I understand. I shouldn't be wondering this, but, legal or not according to your laws, I am still the mother of my daughter." (p. 16, translated)

Nyai Ontosoroh firmly stated her position, she was the mother of her children regardless of the opinion of the Dutch government on the matter. Dutch law could not change her status as a mother. When Tuan Besar Mellema died and the Dutch government tried to disturb Annelies and Minke's relationship, Nyai Ontosoroh bravely opposed them.

"Gentlemen. There was a bond of slavery between Tuan Besar Mellema and me that European law never criticized. There's a sincere love between my daughter and Tuan Minke, even they have been tied in a legal marriage. Again, Sir, Europeans can buy some indigenous woman like me, but nobody protests. Is this trade any better than the sincere love of these two humans? If Europeans are allowed to act because of their superiority and power, why are natives being ridiculed for true love?" (p. 26, translated)

With this statement, Nyai Ontosoroh showed her resistance to two things. First, she opposed the Dutch government regulation that wanted to separate Annelies and Minke's marriage because Annelies was an "indo" (a mix of Dutch and Indonesian blood), while Minke was a native. Second, she showed her resistance to the Dutch government which gave freedom to Europeans who took native women as their concubines. She boldly and courageously showed her criticism of the Judge regarding the injustices received by natives, especially for women, who were Europeans' mistresses. This was supported by the opinion of (Christanty, 1994: 25; Irenewaty \& Adhi, 2016: 18; Setyawan $\&$ Saddhono, 2017) which state that the practice of concubinage was very prevalent during the Dutch administration in the Dutch East Indies, since the formation of the VOC in Batavia. In fact, a governor on the coast of the Java sea allegedly had twenty "favorite" native women (Saddhono.

\section{Conclusion}

"Nyai Ontosoroh" is a drama that presents women's resistance to various gender injustices. She accepted the gender injustice which was deliberately sold by his father for promotion. She lost her rights as a child and as a human who lived in society. Even though her father intended to marry him to Tuan Besar Mellema, she only ended up as a concubine, and it made society looked down on her. In addition, her status as a concubine also made her lose her custody of her own children.

The various gender injustices received by Nyai Ontosoroh made her take up various challenges in 
order to restore her dignity and defend her children. She confidently broke off her relationship with her parents because they had to know that selling their child would mean losing her child forever. In educating her daughter, Nyai freed Annelies to decide for herself the ending she wanted. Nyai always supported her choice. She did not want her daughter to experience what she felt. Nyai Ontosoroh also boldly showed her resistance to the gender injustice from the Dutch government. She also fought for her daughter's rights as a married person. Nyai had proven that not only deal with domestic problems, women can fight back and stand on their own feet. She was brave and did not fear the Dutch people who had more power than him.

\section{References}

[1] Endraswara, S. (2014). Metode Pembelajaran Drama (Apresiasi, Ekspresi, dan Pengkajian). Yogyakarta: CAPS (Center Of Academic Publising Service).

[2] Fakih, M. (2013). Analisis Gender dan Transformasi Sosial. Yogyakarta: Pustaka Pelajar.

[3] Fernández, J., Quiroga, M. A., Escorial, S., \& Privado, J. (2016). The Gendered Division of Housework. Psicothema, 28(2), 130-136. DOI: $10.7334 /$ psicothe, a2015.169

[4] Hazel, K. L. \& Kleyman, K. S. (2020). Gender and Sex Inequalities: Implications and Resistance. Journal of Prevention \& Intervention in the Community, 48(4), 281292. DOI: $10.1080 / 10852352.2019 .1627079$

[5] Hardini, F. (2016). Citra Kaum Perempuan di Hindia Belanda. MUWAZAH, 8(1), 98-105.

[6] Hole, Y., \& Snehal, P. \& Bhaskar, M. (2018). Service marketing and quality strategies. Periodicals of engineering and natural sciences, 6 (1), 182-196.

[7] Hole, Y., \& Snehal, P. \& Bhaskar, M. (2019). Porter's five forces model: gives you a competitive advantage. Journal of Advanced Research in Dynamical and Control System, 11 (4), 1436-1448.
[8] Irenewaty, T., \& Adhi, W. P. (2016). Eksistensi Perjuangan Wanita Masa Kolonial. $\begin{array}{llll}\text { Istoria, } & 11 & \text { (2), } & 13-27 .\end{array}$ https://doi.org/10.21831/istoria.v12i1.9541

[9] Ismawati. (2011). Metode Penelitian Pendidikan Bahasa dan Sastra. Surakarta: Yuma Pustaka.

[10] Lehtonen, A., Österlind, E., \& Viiret, T. L. (2020). Drama in Education for Sustainability: Becoming Connected through Embodient. International Journal of Education and Art, 21(19). DOI: http://doi.org/10.26209/ijea1n19

[11] Marphantia, A. A., Reid, A., \& Amable, G. (2017). Women's Marriage Age Matters for Public Health: A Review of The Broader Health and Social Implicfation in South Asia. Frontiers in Public Health, 5, 1-23. DOI: 10.3389/FPUBH.2017.00269

[12] Moleong, L. J. (2014). Metodologi Penelitian Kualitatif (Edisi Revisi). Bandung: Remaja Karya.

[13] Nurhidayah \& Nurhayati. (2018). Psikologi Komunikasi antar Gender. Yogyakarta: Pustaka Pelajar.

[14] Puspitasari, A. P., Nurhaeni, I. D. A., \& Muktiyo, W . (2019). Conformity of Javanese Cultural Values in Early Marriage: Case Study of Farmer Family Communication. International Journal of Multicultural and Multireligious Understanding, 6(2), 1-7. DOI:

http:/dx.doi.org/10/18415/ijmmu.v6i2.538

[15] Renggani. (2014). Drama Radio: Penulisan dan Pementasan. Yogyakarta: Penebit Ombak.

[16] Rini, P. C. (2019). Interpretasi Feminisme Tokoh Nyai Ontosoroh dalam Novel Bumi Manusia Tulisan Pramoedya Ananta Toer pada Komposisi Musik Ontosoroh karya Peni Candra Rini. GELAR: Jurnal Seni Budaya, 17(1), 24-30.

[17] Saddhono, K., \& Supeni, S. (2014). The role of dutch colonialism in the political life of Mataram dynasty: A case study of the 
manuscript of Babad Tanah Jawi. Asian Social Science, 10(15), 1.

[18] Sehandi, Y. (2014). Mengenal 25 Teori Sastra. Yogyakarta: Penerit Ombak.

[19] Soeharto, Kuncoro, \& Prahara, S. (2020). The Description of Communal Sharing on Working Wives with Work-family Conflicts (Javanese Family): Indigenous Psychology Approach. Digital Press Social Sciences adn Humanities 5:00012, Proceeding of The 10th International Conference of Indigenous and Cultural Psycology, 1-6. DOI: https://doi.org/10.29037/digitalpress.45347

[20] Setyawan, B. W., \& Saddhono, K. (2017). Eret ceremony as representation of mutual cooperation spirit among coastal society. Journal of Computational and Theoretical Nanoscience, 23(10), 9991-9992.

[21] Sudarta, W. (2017). Pengambilan Keputusan Gender Rumah Tangga Petani pada Budidaya Tanaman Padi Sawah Sistem Subak di Perkantoran. Jurnal Manajemen Agribisnis, 5(2), 59-65.

[22] Sundari, M. S. (2019). Raden Ajeng Kartini: Between Education and Feminism in Letters of Javanese Princess. Martabat: Jurnal Perempuan dan Anak, 3(2), 271-296.

[23] Wilujeng, S. R. (2013). Hak Asasi Manusia: Tinjauan dari Aspek Historis dan Yuridis. Jurnal Humanika, 18(2), 160-170. 